\title{
Inter-Orthodox controversies between Romania and Yugoslavia in the interwar period
}

\begin{tabular}{|c|c|}
\hline $\begin{array}{l}\text { Author: } \\
\text { Paul Brusanov }\end{array}$ & $\mathrm{vski}^{1,2}$ (1) \\
\hline $\begin{array}{l}\text { Affiliations: } \\
\text { 'Department } \\
\text { Theology, Fac } \\
\text { Orthodox The } \\
\text { Blaga Univers } \\
\text { Romania }\end{array}$ & $\begin{array}{l}\text { f Pastoral } \\
\text { ulty of } \\
\text { ology, Lucian } \\
\text { ty, Sibiu, }\end{array}$ \\
\hline $\begin{array}{l}{ }^{2} \text { Department } \\
\text { and Historical } \\
\text { Faculty of The } \\
\text { Religion, Univ } \\
\text { Pretoria, Pret } \\
\text { Africa }\end{array}$ & $\begin{array}{l}\text { f Systematic } \\
\text { Theology, } \\
\text { ology and } \\
\text { ersity of } \\
\text { oria, South }\end{array}$ \\
\hline $\begin{array}{l}\text { Research Proj } \\
\text { Project Leade } \\
\text { Project Numb }\end{array}$ & $\begin{array}{l}\text { ect Registration: } \\
\text { r: J. Pillay @ } \\
\text { er: } 04653484\end{array}$ \\
\hline $\begin{array}{l}\text { Description: } \\
\text { The author is } \\
\text { the research a } \\
\text { Dean Prof. Dr } \\
\text { Faculty of The } \\
\text { Religion, Univ } \\
\text { Pretoria. }\end{array}$ & $\begin{array}{l}\text { participating as } \\
\text { ssociate of } \\
\text { Jerry Pillay, } \\
\text { ology and } \\
\text { ersity of }\end{array}$ \\
\hline $\begin{array}{l}\text { Correspondin } \\
\text { Paul Brusanov } \\
\text { pbrusan@yah }\end{array}$ & $\begin{array}{l}\text { g author: } \\
\text { vski, } \\
\text { oo.de }\end{array}$ \\
\hline $\begin{array}{l}\text { Dates: } \\
\text { Received: } 25 \\
\text { Accepted: } 16 \\
\text { Published: } 21\end{array}$ & $\begin{array}{l}\text { May } 2021 \\
\text { uly } 2021 \\
\text { Sept. } 2021\end{array}$ \\
\hline $\begin{array}{l}\text { How to cite th } \\
\text { Brusanowski, } \\
\text { 'Inter-Orthod } \\
\text { between Rom } \\
\text { Yugoslavia in } \\
\text { period', HTS T } \\
\text { Studies/Theol } \\
77(4), \text { a6865. } \\
\text { org/10.4102/ }\end{array}$ & $\begin{array}{l}\text { is article: } \\
\text {., 2021, } \\
\text { x controversies } \\
\text { ania and } \\
\text { he interwar } \\
\text { ologiese } \\
\text { gical Studies } \\
\text { ttps://doi. } \\
\text { ts.v77i4.6865 }\end{array}$ \\
\hline $\begin{array}{l}\text { Copyright: } \\
\text { (c 2021. The } \\
\text { Licensee: AOS } \\
\text { is licensed un } \\
\text { Creative Com } \\
\text { Attribution Lic }\end{array}$ & $\begin{array}{l}\text { uthors. } \\
\text { S. This work } \\
\text { ler the } \\
\text { nons } \\
\text { ense. }\end{array}$ \\
\hline Read online: & \\
\hline 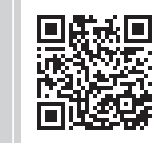 & $\begin{array}{l}\text { Scan this QR } \\
\text { code with your } \\
\text { smart phone or } \\
\text { mobile device } \\
\text { to read online. }\end{array}$ \\
\hline
\end{tabular}

This article examines the disputes that existed in the interwar period over the recognition of a Romanian Orthodox bishopric in Yugoslavia (The official name 'Yugoslavia' was only adopted in 1929. From 1918 to 1929, the state was officially called the Serbo-Croatian-Slovenian Kingdom. For the sake of simplicity, I will use the name Yugoslavia throughout this article.) and a Serbian Orthodox bishopric in Romania. The reason for this was the existence of two ethnically distinct Orthodox Churches (Serbian and Romanian) on the territory of the dualistic Hungarian monarchy before 1918, but both with de facto autocephalous status and territorial overlap. They came into being after the decision of the Synod of Bishops of the Hungarian Orthodox Metropolis to separate the existing parishes and dioceses along ethnic lines. After the break-up of the dualistic monarchy at the end of the First World War, one of the Serbian Orthodox dioceses landed on the territory of Yugoslavia (Vršac) and the second on the territory of Romania (Timişoara). However, both Romanian bishoprics (Arad and Caransebeș) ended up in Romania. Under these circumstances, several Romanian parishes in the Yugoslav Banat remained without a direct episcopal hierarchy. As a result, diplomatic negotiations began between the Romanian and Yugoslav governments and between the hierarchs of the Orthodox Churches of Romania and Yugoslavia on the establishment of a Romanian diocese on Yugoslav territory.

Contribution: This article deals with a lesser-known topic on the history of the Orthodox Churches in South Eastern Europe. Because there is no extensive literature on this subject, I have made use of unpublished documents from the archives of the Metropolitanate of Sibiu (Transylvania, Romania).

Keywords: Romania; Yugoslavia; Banat; Romanian Orthodox Church; Serbian Orthodox Church.

\section{Introduction}

The subject is little known in church historiography. The Catholic church historian Cölestin Wolfsgruber drew up a map of the two Orthodox churches in Hungary (the Serbian and the Romanian churches) but did not consider the reality of territorial overlaps (Wolfsgruber 1909), which Thomas Nemeth also mentions (Németh 2014:7). The same situation is also presented in more recent atlases (e.g. ed. Magosci 2002:Map 35).

\section{What 'the hierarchical separation' of the Romanians from the Serbian hierarchy meant}

Before 1864, there was only one Orthodox Church in Habsburg Hungary, led by the Metropolitan of Srijemski Karlovci, with seven suffragan bishoprics on the territory of Hungary and three other dioceses outside Hungary (one each in the provinces of Dalmatia, Transylvania and Bukovina). In 1809, the metropolis on the territory of Hungary comprised 1505 parishes, of which 935 were Serbian, 553 Romanian (i.e. 36.74\%) and 17 Greek (Schwartner 1809:I 179). The Romanian parishes were in the diocese of Arad and in two other dioceses (Timişoara and Vršac) in the historical region of Banat $\left(27637 \mathrm{~km}^{2}\right)$, which lies between the rivers Danube, Tisza, Mureș and Southern Carpathians.

In 1864, the entire diocese of Arad as well as the Romanian parishes in Banat (from the dioceses of Timişoara and Vršac) were placed under the jurisdiction of the new Romanian Orthodox Metropolitanate: a small part of Banat was placed under the jurisdiction of the diocese of Arad, and for the other parts of Banat was established the new Romanian diocese of Caransebeș. The Serbian parishes remained under the jurisdiction of the Serbian Church, that is, the two old Serbian eparchies of Timişoara and Vršac.

Note: Special Collection: Lucian Blaga University, Sibiu, Romania, sub-edited by Daniel Buda (Lucian Blaga University) and Jerry Pillay (University of Pretoria). 
The Hungarian Parliament, formed after the AustroHungarian Compromise, recognised the existence of the two Orthodox Churches (Metropolitanates) in Hungary in 1868. The constitution of the Romanian Church in Hungary, sanctioned in 1869, provided for the creation of a joint synod of the metropolitans and bishops of the two churches in Hungary, with the aim of 'preserving dogmatic and canonical unity'. However, this synod never met, mainly because of 'the hierarchical separation and the lawsuits that were conducted for the purpose of this separation', so that relations between the two churches 'hardened and a kind of enmity arose between them' (Preda 1914:71).

The hierarchical separation of the Romanian faithful was painful for the Serbs. On the one hand, localities with a large Romanian majority came under the jurisdiction of the Romanian Church. On the other hand, the Romanians themselves founded new Romanian parishes in places where they were in the minority. This led to court cases about the division of material goods. The law passed by the Hungarian Parliament established three judicial instances for these trials, which were conducted until 1918. Those responsible for the hierarchical separation reported to the National Church Congress $^{1}$ in Sibiu in 1916 that as a result of all these trials about 70000 ethnic Romanian Orthodox believers (about $14 \%$ of the Romanian population of the Banat), who were minorities in their localities, were integrated into new parishes under the jurisdiction of the Romanian Church (Protocols CNB_SB 1916:194). In October 1918, there were still lawsuits for five parishes, including those in the important localities of Pančevo and Vršac (MA 1918.10.08).

\section{The division of the historic Banat region after the end of the First World War}

The armistice agreement signed between the Entente and Hungary on 13 November 1918 allowed Serbia to occupy the entire Banat region; Romania, however, only the southern and eastern parts of the Transylvania. The Serbian army began preparations for the incorporation of the Banat into the Yugoslav state. Numerous Romanian priests were arrested because they mentioned King Ferdinand of Romania and not King Peter of Serbia in the liturgy. At the insistence of the Romanian government, French troops occupied the mountainous (eastern) part of Banat (end of January 1919). The Serbs continued to occupy the western part of the province. Everywhere, however, the old Hungarian civil administration remained (Alic 2014:356-369). A diplomatic conflict broke out between Romania and Yugoslavia over the Banat - both states claimed the entire territory at the peace conference (Spector 1995:149-152).

The Council of Four of the Paris Peace Conference approved the new border between Romania and Yugoslavia and the division of the Banat region between 11 and 13 June 1919.
Finally, it was then legally recognised internationally in the 3rd article of the Treaty of Sèvres of 10 August 1920 on the establishment of new borders of Poland, Czechoslovakia, Romania and Yugoslavia (Campus 1980:230-233). Approximately two-thirds of the Banat fell to Romania and one-third to Yugoslavia. Hungary retained only a small part of the Banat, near Szeged.

The Serbian army did not withdraw within the Yugoslav borders until the end of July 1919 (20-28 July 1919), when the Romanian army took over the new territory of Eastern Banat.

A large Serbian minority (in Romania) or Romanian minority (in Yugoslavia) continued to live in both parts of the Banat. The first census in Yugoslavia (1921) revealed 67897 Romanians in the Serbian Banat, which corresponded to about $12 \%$ of the total population of the region (Census Yugoslavia 1921:2). Apart from six parishes, which were under the jurisdiction of the Diocese of Arad, the other parishes were under the jurisdiction of the Diocese of Caransebeș.

As for the 'Yugoslavs' (i.e. Serbs and Croats) in the Romanian Banat, according to the first Romanian census (1930), they formed a minority of $4.3 \%$ of the region's population (Manuilă \& Georgescu 1938:148).

\section{The move of Bishop Georgje Letić from Timișoara to Kikinda and the appointment of a Serbian vicar in Timișoara (1919)}

With the retreat of the Serbian troops, the Serbian Bishop of Timișoara, Georgje Letić, left Romania and moved to Kikinda (Yugoslavia). After the retirement of Bishop Ilarion Radonić of Vršac (1929), Letić became the administrator of this eparchy. It was not until 1931 that Letic remained the only bishop of the Yugoslav Banat, in the reorganised Serbian Orthodox eparchy called Banat and with its seat in Vršac.

Whilst he was in Kikinda, Letić appointed Archimandrite Stefan Nikolić as 'vicar for the part of the diocese of Timişoara that lies on Romanian territory'. Nikolić was recognised by the Transylvanian Governing Council' as 'episcopal vicar for the Serbian Greek Orthodox Church of Timişoara' on 01 December 1919. It is already evident from the two titles that the Minister for Religious Affairs in the Governing Council (Valeriu Braniște) did not fully understand the problems of the Serbian Church in the Banat and believed that Nikolić was only performing an administrative function in the diocese of Timişoara. Instead, Letić's signed deed of appointment stated that 'the part of the Diocese of Timişoara that remains under the Romanian government will be administered independently and separately from the Directorate of the Serbian Diocese of Kikinda'. Thus, the Serbian Orthodox Church (SOC) has

2.The Governing Council was the provisional government of Transylvania until 04 April 1920, when the full administrative unification of the interwar Romanian state took place. 
created a new reality, that of a Vicariate for Serbian Orthodox in Romania (MA 1 n.d.).

\section{The Yugoslav-Romanian Commissions for Intergovernmental Dialogue and the Timișoara Convention (1923)}

The talks about the churches in the two parts of the Banat were firstly conducted by the foreign ministries of Romania and Yugoslavia. On 07 June 1921, with the signing of the protocols on the establishment of the Little Entente, the diplomats agreed that:

$[B]$ oth governments will appoint delegates as soon as possible to study and negotiate the settlement of the question of the Romanian churches and schools in the Serbian Banat and the Serbian churches, schools and monasteries in the Romanian Banat on the basis of mutual treatment. (MA 1933.06.23)

Subsequently, two working meetings of the two sides took place in Belgrade (02 October 1922) and Timișoara (19 November 1923). Traian Oprea, the Romanian archpriest of Vršac, took part in the first meeting on the Romanian side, and a diocesan advisor from Caransebes in the second. The Serbian Bishop Letić and Vicar Nikolić were part of the Yugoslav commission.

At the second meeting, it was agreed to establish an Orthodox vicariate in each country, headed by an 'episcopal vicar' (i.e. a vicar ordained as a bishop) - in Timișoara for the Serbs in Romania and in Vršac for the Romanians in Yugoslavia. The vicars were to be subordinate to the bishops of the local dioceses, namely Arad, in the case of the Serbian vicar in Romania, and Vršac, in the case of the Romanian vicar in Yugoslavia. In disciplinary terms, the vicars were to be subject to the Holy Synod of the Orthodox Church of the country in which they resided.

The Timisoara Convention of 1923 created a new ecclesiastical situation and practically separated the Orthodox believers from their national churches, under whose jurisdiction they had previously been.

After the talks, however, the Serbs changed their minds and asked for the reactivation of the old Serbian diocese of Timisoara in Romania (although it was actually they who had moved it to Kikinda). But at Romanian request, they were not prepared to recognise a Romanian diocese in Yugoslavia. The negotiations were therefore suspended (FD 1923:3).

But even the leadership of the Romanian Orthodox Church (ROC) was not satisfied with the vicariate solution either. In 1920, 1921 and 1924, the CNB_SB continued to take the view in several decisions that the Romanian faithful in the Yugoslav Banat remained under the jurisdiction of the dioceses of Arad and Caransebeș (Protocols CNB_SB 1924:38-40).
Resumption of the talks between 1927 and 1929 with the participation of the Metropolitanate of Transylvania

It was not until 1926 that the governments of the two countries decided to resume the talks. This time the Romanian commission included two representatives of the Transylvanian Metropolitanate - the historian Silviu Dragomir (professor at the University of Cluj) and the lawyer George Dobrin from Lugoj (MA 1926.07.31).

In view of these negotiations, on 12 October 1926, the Metropolitan Council $^{3}$ from Sibiu laid down the following principles: either to retain the parishes in Yugoslavia within the dioceses based in Romania or to establish, on the basis of reciprocity, a diocese or vicariate for the Romanians of the Yugoslav Banat, but in such a way as to preserve the Romanian national character (MA 1929.04.24).

The Romanian-Yugoslav Dialogue Commission met in Timisoara in February 1927 and then in Bled, Yugoslavia (now Slovenia) in August 1927. Here a convention on school matters was signed on 17 August. The discussion on church matters was postponed (Aleksandra Djuric \& Măran 2019:70-71).

But in July 1927, the Romanian minister in Belgrade, Victor Iamandi, sent a confidential telegram to the Romanian Foreign Ministry about the church negotiations. Because the Serbs did not accept Romanian ecclesiastical autonomy on Yugoslav territory, Iamandi proposed to the Yugoslavs the establishment of two new bishoprics in the Banat on a reciprocal basis. Iamandi waited for a reaction from Bucharest (MA 2027.07.19).

At the request of the Romanian government, the Metropolitan Council of Sibiu discussed Iamandi's proposal and decided to keep the opinion of October 1926. It took the view that the establishment of new bishoprics could only be 'a minimum requirement' (MA 1929.04.24).

The Romanian-Yugoslav commission met again between 15 April and 03 May 1929, but no result was reached. The Romanian delegation proposed that the Serbian Orthodox in Romania should come under the jurisdiction of the Serbian diocese of Kikinda and the Romanian Orthodox in Yugoslavia under that of the Romanian diocese of Caransebeș. According to Silviu Dragomir, the Romanians could not give up a right they had already won during the Hungarian administration, namely the existence of the Romanian national church. The existence of a Romanian vicariate under the Serbian hierarchy would have meant that the Romanian Church in Yugoslavia would have become a tolerated church. The Serbian delegation replied that it could not allow two Orthodox churches to exist in the same state. Instead, it proposed an 'extension of competence' of the Romanian Church in Yugoslavia, but 'on condition that the Romanian Church is under the supremacy and jurisdiction of the Serbian Church'. 3.The Metropolitan Council was the supreme executive body of the Metropolitanate. 
When asked to explain the conditions, Letic said that the Serbs had offered 'a more perfect organisation' for the Romanian Church and that the supremacy and jurisdiction should mean at least a dependence in dogmaticis et spiritualibus on the local Serbian bishop. Silviu Dragomir thought that the Serbian proposal itself contained a contradiction and asked for the right to consult the Romanian authorities (MA 1929.11.13).

The Metropolitan Council of Sibiu decisively rejected the proposal of the Serbian side on 24 April 1929:

The Romanians in the former Hungary have a rich experience of national intolerance hiding behind a dependency, even if only dogmatic and spiritual, and thus we cannot allow a new ecclesiastical and national slavery for our believers in the Serbian Banat.

We take the liberty of drawing your kind attention to the way in which the former Hungarian state solved the problem of the Orthodox Church at the time: It allowed the formation of two ... autocephalous Orthodox Churches, on a national basis. ...

If great state interests would require the withdrawal of our faithful from their hierarchical bond with our Metropolitanate, I believe they must at least be assured and guaranteed autonomy and ecclesiastical autocephaly. (MA 1929.04.24)

\section{The Negotiations of 1933 and the Signing of the Convention of 02 May 1934}

On 19 December 1932, a meeting of the Little Entente took place in Belgrade. The foreign ministers of Romania and Yugoslavia resumed negotiations on various bilateral issues. Nineteen agreements were signed between the two countries, with only the question of church organisation remained open.

On 12 January, the Romanian-Yugoslav Dialogue Commission for Church Affairs met again. On 17 January, the Serbian delegation proposed the establishment of a joint synod, which would act as a mediating body between the synods of bishops of the two churches and would consist of two Romanian and two Serbian bishops. Its competences were to be limited to caring for the preservation of the faith and the rite in the two vicariates, the ordination of episcopal vicars, their supervision and discipline, and the defence of the canonical and autonomous rights of the churches within the framework of the interconfessional legislation of the two states (MA 1933.01.20; MA 1933.03.01).

The Romanian delegation agreed to this proposal. Even Metropolitan Nicolae Bălan of Sibiu accepted this in a letter of 23 January 1933 to Foreign Minister Titulescu, if 'nothing more could be done' (MA 1933.01.23).

A draft convention was drawn up. The minority churches in the two countries were to have full autonomy as national churches. They were to be led by an episcopal vicar elected by the eparchial assembly of the respective church. In purely dogmatic and spiritual matters, the episcopal vicars were to be under the authority of the Joint Synod, which was to meet annually, alternately in Romania in Timișoara and in
Yugoslavia in Vârșeț, presided over by a Romanian hierarch in the case of matters concerning the Serbian Church in Romania, or by a Serb in the case of matters concerning the Romanian Church in Yugoslavia. The use of the mother tongue was guaranteed for both churches (MA 1933.03.17).

However, on 24 February, the Serbian delegation announced that the Holy Synod of the SOC would not agree to the establishment of this Joint Synod (MA 1933.10.16). Under these circumstances, the Romanian minister in Belgrade, Alexandru Iacovsky, together with the Yugoslav foreign minister, Boguljub Jeftić, proposed a direct meeting of the representatives of the synods of both churches (MA 1933.03.17). Because the Serbian bishops refused to travel to Bucharest, the Patriarch of Romania instructed the Metropolitan of Transylvania to travel to Belgrade to negotiate with the hierarchs of the Holy Synod of the Serbian Church (MA 1933.03.31).

Metropolitan Bălan was accompanied by the Bishop of Arad Grigore Comșa. Both arrived in Belgrade on 01 May. The talks turned out to be difficult and so the two Romanian bishops wanted to leave Belgrade on 10 May, but were stopped on their way to the railway station by a telegram from the Foreign Ministry in Bucharest. Finally, on 15 May, a Church Convention was signed by both sides, which contained 15 articles and five annexes on material issues such as Church property, monasteries, salaries, citizenship and the right of priests to catechise (Aleksandra Djuric \& Măran 2019:215-226).

A summary of the talks was reported by Metropolitan Bălan to the Ministry of Foreign Affairs and the Holy Synod in Bucharest (MA 1933.n.d.), as well as to the National Church Congress in Sibiu (MA 1933.10.16).

From the beginning, the Romanian delegation used the term 'fragments' to define the situation of the ethnic Romanian and Serbian Orthodox minority churches in the two states and emphasised the right of the ROC to have jurisdiction over the 'church fragment' of the Romanian Orthodox in Yugoslavia, just as the SOC already had jurisdiction over the 'church fragment' of the Serbian Orthodox in Romania. The Romanians categorically rejected the SOC position of applying the principle of the existence of a single Orthodox Church on the territory of a state, citing the example of Serbian jurisdiction in the Italian region of Zadar in Dalmatia, even though the dioceses of the Dodecanese existed on the territory of the Italian state:

It is therefore not the canon and ecclesiastical practice that oppose the solution proposed by the Romanian Commission, but quite different considerations. The Serbian Patriarchate crosses the borders of other countries without scruples in order to exercise jurisdiction, but it does not even allow links of spiritual jurisdiction between the fragments of an Orthodox Church, which as a merited right has the character of a Romanian national Church, and its mother Church, which remains beyond the border, even if this Church belongs to a friendly and allied state. (MA 1933.n.d.:1) 
On the other hand, the Serbian bishops replied that they could not accept a convention whose framework was set by the state authorities. They reiterated the position they had held since 1923 and were prepared to grant the Romanian Church in Yugoslavia autonomy in administrative and material matters but continued to claim the jurisdiction in spiritual matters of the local hierarch. The idea of a joint synod seemed uncanonical to them. On the other hand, they were ready to accept a mixed commission to settle conflicts and disagreements, if it was not of a permanent nature and could not take final decisions.

\section{Romanian Metropolitan Nicolae Balan assured the Serbs:}

This Commission does not constitute an independent forum of the Churches but derives its limited rights and powers from the spiritual power of the two Churches, from the holy canons and their holy patriarchs, and acts solely by virtue of the delegation received from them. It is thus the expression of a willed cooperation between the two Churches for a certain common end; spiritually speaking, it is as if the two Churches were pooling their blessings and love and thus transferring them to the two eparchies. (MA 1933.n.d.:7)

The convention adopted by the Serbian and Romanian hierarchs on 15 May was little different from the one agreed by the diplomats on 02 February. Firstly, the title joint synod was no longer used, instead the term mixed commission was used. It was also not envisaged that it should meet periodically, that is, annually, but only when necessary.

The convention was presented by Nicolae Balan as the maximum that could be achieved in the long negotiations with the Serbs, being sure that:

The joint synod or mixed commission, or whatever we want to call it, is the only formula under the circumstances to save the connection with the mother church. (MA 1933.06.07)

Most importantly, the Convention clearly stated that the pre-1918 Statutes of Organisation remained in force in both minority churches, which now gave the Romanian Church in Yugoslavia full autonomy vis-à-vis the government in Belgrade (just as it had given the Transylvanian Metropolitan Church in Sibiu autonomy vis-à-vis the government in Budapest).

The Church Convention signed by the Serbian and Romanian bishops was adopted by the Holy Synod of the ROC. It was signed by the representatives of the Kingdom of Romania and the Kingdom of Yugoslavia on 02 May 1934. The Romanian Parliament ratified the Convention, but not the Yugoslav Parliament (Romanian Patriarchate 1939:25).

\section{Epilogue}

The Convention of 1933/1934 never came into force. During the time of the communist dictatorship, there were Romanian and Serbian vicariates (led by archpriests, without episcopal ordination) in Vršac and Timișoara. It was not until 2006 that there were some changes on the Romanian side. On the one hand, the Law on Religion which was adopted in that year by the Romanian Parliament and published in the Official Gazette on 08 January 2007, provided for the Serbian Diocese of Timișoara as part of the SOC the status of a recognised religious community amongst the 18 recognised denominations (Law 489 2006, Annex). On the other hand, in November 2006, the Holy Synod of the Romanian Patriarchate established the diocese of Dacia felix for Romanians in Serbia, with its seat in Vršac. Originally it was part of the Romanian Metropolitan Province of Banat (Statute 2008:Art. 6). With the amendment of the Statute in 2020, it was placed directly under the Romanian Patriarchate (Statute 2020:Art. 6). ${ }^{4}$

In Serbia, six traditional religious communities were listed in the 2006 Law on Religion, as well as other denominational communities recognised by the Yugoslav state in 1953 and 1977. The Romanian diocese of Dacia Felix in Vršac was recognised as a traditional religious community by the Serbian government only in April 2009 (Raković 2009:1). This effectively ended the dispute over the Orthodox minority churches in the Banat, which was divided between Romania and Yugoslavia in 1919.

\section{Conclusions}

The negotiations about the legal and canonical status of the Romanian Orthodox in Yugoslavia/Serbia and the Serbian Orthodox in Romania were difficult from the beginning:

1. The conditions for this were set during the time of the old Austro-Hungarian monarchy and the separation of the Romanian Orthodox faithful from the Serbian hierarchy in the second half of the 19th century.

2. The negotiations were based on different canonical principles. Whilst the Serbian bishops supported the territorial principle (the existence of a single Orthodox Church in one state), the Romanian bishops invoked the ethnic principle.

3. In 1933-1934, a compromise was accepted that was not implemented at the time. On the one hand, the administrative and financial autonomy of the two dioceses of Vršac and Timișoara was recognised, and on the other hand, it was imposed the spiritual jurisdiction of the local hierarch. As a concession to the Romanian bishops, the establishment of a joint commission of bishops from both the churches to monitor compliance was allowed.

4. Finally, between 2006 and 2009, a solution prevailed which the Serbian bishops were not even prepared to accept during the negotiations of 1923-1933 - full administrative and spiritual (jurisdictional) autonomy of the two Orthodox Banat minority dioceses in Romania and Serbia.

\section{Acknowledgements Competing interests}

The author declares that he has no financial or personal relationships that may have inappropriately influenced him in writing this article.

4.I have not yet found an English translation of the amended statutes. 


\section{Author's contributions}

P.B. is the sole author of this article.

\section{Ethical considerations}

This article followed all ethical standards for research without direct contact with human or animal subjects.

\section{Funding information}

This research received no specific grant from any funding agency in the public, commercial or not-for-profit sectors.

\section{Data availability}

Data sharing is not applicable to this article as no new data were created or analysed in this study.

\section{Disclaimer}

The views and opinions expressed in this article are those of the author and do not necessarily reflect the official policy or position of any affiliated agency of the author.

\section{References}

Aleksandra Djuric, M. \& Măran, M., 2019, Biserica Ortodoxă Română din Banatul iugoslav în perioada interbelică (1918-1941), Presa Universitară Clujeană, Cluj-Napoca.

Alic, D., 2014, Eparhia Caransebeșului în perioada păstoririi episcopului Miron Cristea (1910-1919), Presa Universitară Clujeană - Editura Episcopiei Caransebeșului, Cluj Napoca.

Campus, E., 1980, Din politica externă a României. 1914 1947, Editura Politică, București.

Census Yugoslavia, 1921, Podaci za srez (kotar) i obshtine nalaze se u kniz 'Definitivni rezultati POPISA STANOVNISHTVA' od 31. januara 1921, Godine, viewed 02 April 2021, from https://pod2.stat.gov.rs/ObjavljenePublikacije/ G1921/PDF/G19214001.pdf.

De Preda, I.A., 1914, Constituția bisericei gr.-or. Române din Ungaria și Transilvania sau Statutul Organic comentat și cu concluzele și normele referitoare întregit, Tiparul tipografiei arhidiecezane, Sibiu.

FD, 1923, 'Tratativele comisiunii româno-jugoslave dela Timișoara' [Verhandlungen der Rumänisch-Jugoslawischen Kommission in Timisoara], Foaia Diecezană, no. 47/2 December, p. 3, viewed 02 April 2021, from BCUCLUJ_FP_279423_1923_038_ 047.pdf.

Law 489, 2006, Law on the Freedom of Religion and the General Status of Denominations, viewed 02 April 2021, from https://www.legislationline.org/ download/id/3107/file/Law $\% 20$ on $\% 20$ the $\% 2$ Freedom $\% 20$ of $\% 20$ Religion $\% 20$ adopted $\% 20$ on $\% 208 \% 20 J a n u a r y \% 202007$.pdf.

MA 1, n.d., Fond lugoslavia: 'Memoriu asupra numirii ca vicar episcopesc sârb în Timișoara a dlui Ștefan Nikolić', Metropolitanate Archives, Sibiu.

MA, 1918.10.08, Fond Iugoslavia: Raportul Delegației Congresuale către CongresulNațional-bisericesc din Sibiu privitor la Despărțirea ierarhică, Metropolitanate Archives, Sibiu.

MA, 1926.07.31, Fond lugoslavia: Adresa nr. 41.060 din 31 iulie 1926 a Ministerului Afacerilor Străine către Ministerul Cultelor și Artelor, Metropolitanate Archives, Sibiu.
MA, 2027.07.19, Fond lugoslavia: Mesaj confidențial al ministrului român la Belgrad către Ministerul Afacerilor Externe din București din 19 iulie 1927, Metropolitanate Archives, Sibiu.

MA, 1929.04.24, Fond Iugoslavia: Adresa nr. 83 / 24. aprilie 1929 a mitropolitului Nicolae Bălan către ministrul de Externe al României, George Mironescu, Metropolitanate Archives, Sibiu.

MA, 1933.n.d., Fond lugoslavia: Raport al mitropolitului Nicolae Bălan către Sf. Sinod si Ministerul Afacerilor străine despre tratativele de la Belgrad, Metropolitanate Archives, Sibiu.

MA, 1933.01.20, Fond lugos/avia: Comunicarea Legațiunii noastre din Belgrad primită la Ministerul Afacerilor Străine la 20 ianuarie 1933 pentru mitropolitul Nicolae, Metropolitanate Archives, Sibiu.

MA, 1933.01.23, Adresa nr. 31 din 23 ianuarie 1933 a Mitropoliei Ardealului către ministrul de Externe Titulescu, Metropolitanate Archives, Sibiu.

MA, 1933.03.01, Fond lugoslavia: Raportul nr. 3, din 1 martie 1933 al Delegație române la Belgrad adresat Ministerului Afacerilor Externe cu privire la negocierile din cadrul Comisiei de Dialog, Metropolitanate Archives, Sibiu.

MA, 1933.03.17, Fond lugos/avia: Adresa nr. 12.329 din 17 martie 1933 a Ministerulu Afacerilor Străine către Mitropolia Ardealului, Metropolitanate Archives, Sibiu.

MA, 1933.03.17, Fond lugoslavia: Adresă oficială nr. 12.943 din 17 martie 1933 trimisă de Ministerul Afacerilor Străine din București către Mitropolia Transilvaniei, Metropolitanate Archives, Sibiu.

MA, 1933.03.31, Fond Jugoslavia: Telegrama nr. 3441 din 31 martie 1933 a Patriarhulu Miron Cristea către mitropolitul Nicolae Bălan, Metropolitanate Archives, Sibiu.

MA, 1933.06.07, Fond Iugoslavia: Scrisoare a mitropolitului Nicolae Bălan către episcopul Traian Bădescu de la Caransebeș despre tratativele de la Belgrad din mai 1933, Metropolitanate Archives, Sibiu.

MA, 1933.06.23, Fond Iugoslavia: Adresa Ministerului Afacerilor Externe către Mitropolitul Nicolae Bălan, nr. 32590/23 iunie 1933, Metropolitanate Archives, Sibiu.

MA, 1933.10.16, Fond lugoslavia: Raport al mitropolitului Nicolae Bălan din 16 octombrie 1933 către Congresul Național Bisericesc de la Sibiu, Metropolitanate Archives, Sibiu.

MA, 1929.11.13, Fond lugoslavia, 'Românii ortodocși din Banatul iugoslav. Acte depuse la dosar la 13 noiembrie 1929 de dl. Silviu Dragomir', Metropolitanate Archives, Sibiu.

Magosci, P.R. (ed.), 2002, Historica atlas of central Europe from the early fifth century to the present, rev. and expanded edn., Thames \& Hudson, London.

Manuilă, S. \& Georgescu, M., 1938, 'Populația României', in D. Gusti (ed.), Enciclopedia României tipărită sub patronajul regelui Carol II, vol. 1, p. 148, Imprimeria Națională, București.

Németh, T., 2014, 'Die orthodoxe Kirche in der Habsburgermonarchie. Geschichte und Strukturen', Ostkirchliche Studien 63, 7.

Protocols CNB SB, 1916, Protocolul Congresului Naţional-Bisericesc ordinariu a Metropoliei românilor greco-orientali din Ungaria şi Transilvania pe anul 1916, Tiparul tipografiei arhidiecezane, Sibiu.

Protocols CNB SB, 1924, Protocolul Congresului Naţional-Bisericesc ordinariu al Metropoliei românilor greco-orientali din Ungaria și Transilvania pe anul 1924, Tiparul tipografiei arhidiecezane, Sibiu.

Raković, A., 2009, Statement by the Adviser to the Minister of Religious Affairs of the Republic of Serbia, Mr Aleksandar Rakovic, viewed 02 April 2021, from https:// www.osce.org/odihr/39368.

Schwartner, V.M., 1809, Statistik des Königreiches Ungarn, Königliche UniversitätsSchriften, Buda.

Spector, S.D., 1995, România la Conferința de Pace de la Paris, Institutul European, lași.

Statute, 2008, The Statute for the organisation and functioning of the Romanioan Orthodox Church, viewed 02 April 2021, from http://www.orthodoxero.eu/
media/Documents/STATUTES\%20FOR\%20THE\%20ORGANISATION\%20OF\%20 media/Documents/STATUTES\%20FOR\%20TH.

Statute, 2020, Statutul pentru organizarea si functionarea Bisericii Ortodoxe Române, publicat în Monitorul Oficial din 10 februarie 2020, viewed 02 April 2021, from publicat in Monitorul Oficial din 10 februarie 2020, viewed 02 April 2021, from si\%20functionarea\%20Bisericii\%200rtodoxe\%20Romane.pdf.

Wolfsgruber, 1909, Cölestin Wolfsgruber, Kirchengeschichte Österreich-Ungarns, Heinrich Kirsch, Wien, Leipzig. 